\title{
DEFINING OUTCOME IN ACUTE STROKE PATIENTS USING BARTHEL INDEX AND MODIFIED RANKIN SCALE TREATED WITH NEUROPROTECTIVE AGENTS
}

\author{
INDER PAL SINGH*, KAMALDEEP KAUR, LOVLEEN BHATIA, AJAY PAL \\ Department of Medicine, Government Medical College, Patiala, Punjab, India. Email: drinderpal@gmail.com
}

Received: 31 January 2021, Revised and Accepted: 07 June 2021

ABSTRACT

Objective: The present study was carried out to describe outcome in acute stroke patients by means of Barthel index (BI) and modified Rankin scale (mRS) treated with neuroprotective agents.

Methods: One hundred acute stroke patients were divided into two groups. Group I patients were treated with citicoline as neuroprotective agent and Group II patients were treated with cerebroprotein hydrolysate as neuroprotective agent. BI and mRS were applied at $1^{\text {st }}, 3^{\text {rd }}, 6^{\text {th }}$ and $12^{\text {th }}$ week respectively.

Results: The mean BI at $1^{\text {st }}$ week in Group I was 35.3 and in Group II was 36.2 , at $3^{\text {rd }}$ week was 50.5 in Group I and 50.1 in Group II, at $6^{\text {th }}$ week was 61.4 in Group I and 59.8 in Group II and at $12^{\text {th }}$ week was 65.8 in Group I and 64.2 in Group II. The difference was non-significant (p>0.05). The mean $\mathrm{mRS}$ at $1^{\text {st }}$ week in Group I was 4.5 and in Group II was 4.2, at $3^{\text {rd }}$ week was 3.6 in Group I and 3.9 in Group II, at $6^{\text {th }}$ week was 3.1 in Group I and 3.6 in Group II and at $12^{\text {th }}$ week was 2.5 in Group I and 2.1 in Group II. The difference was non-significant $(p>0.05)$.

Conclusion: A correlation between BI and mRS from baseline to end of 12 weeks within each group was highly significant.

Keywords: Stroke, Barthel index, Modified Rankin scale.

(C) 2021 The Authors. Published by Innovare Academic Sciences Pvt Ltd. This is an open access article under the CC BY license (http://creativecommons.org/ licenses/by/4.0/) DOI: http://dx.doi.org/10.22159/ajpcr.2021v14i8.40959. Journal homepage: https://innovareacademics.in/journals/index.php/ajpcr

\section{INTRODUCTION}

Stroke, a swift neurologic deficit of specious vascular origin, is a clinical syndrome rather than a solitary disease. A recurrent and stressful condition causes death of one-third of patients at 6 months and leaves another third perpetually reliant on the care of others [1]. Every year in the UK, 110,000 cases of fresh strokes and 30,000 cases of recurring strokes occurred; 10,000 strokes happened in younger individuals and 60,000 individuals died of stroke. It is the main reason of debility, and $>5 \%$ of the National Health Commission and social services assets are disbursed by stroke patients. Precise management relies on quick diagnosis and treatment, exhaustive investigation, and rehabilitation [2].

Substantial efforts are made to develop drug treatments that may reduce brain damage and improve aftermath in patients with ischemic stroke. Barthel index (BI) is considered as consistent disability scale for stroke patients [3]. The items may be separated into a group that is related to self-care (feeding, bathing, grooming, dressing, bowel, and bladder care) and a group related to mobility (ambulation, stair climbing, and transfers), The maximal score is 100 if five-point increments are applied, representing that the patient is fully independent in physical working. The lowest score is zero, representing a totally reliant on bedridden state [4]. The modified Rankin scale (mRS) measures independence rather than performance of specific tasks. By this track, psychological and corporal adjustments to the neurological defects are assimilated. The scale consists of six grades, from zero to five, with zero corresponding to no symptoms, and five corresponding to severe disability [5]. The present study was conducted to express consequence in acute stroke patients using $\mathrm{BI}$ and $\mathrm{mRS}$ treated with neuroprotective agents.

\section{METHODS}

The present study was conducted on 100 acute stroke patients of both genders. All were informed regarding the study and their written consent was taken. Ethical clearance was taken before starting the study.

Data such as name, age and gender was recorded. Patients were divided into two groups. Group I patients were treated with citicoline as neuroprotective agent and Group II patients were treated with cerebroprotein hydrolysate as neuroprotective agent. We applied both the $\mathrm{BI}$ and $\mathrm{mRS}$ at $1^{\text {st }}, 3^{\text {rd }}, 6^{\text {th }}$, and $12^{\text {th }}$ week respectively. Results were tabulated and subjected to statistical analysis. $\mathrm{p}<0.05$ was considered significant.

\section{RESULTS}

Table 1 shows that Group I patients were treated with citicoline and Group II with cerebroprotein hydrolysate. Each group had 50 patients.

Table 2 and Graph 1 shows that mean BI at $1^{\text {st }}$ week in Group I was 35.3 and in Group II was 36.2, at $3^{\text {rd }}$ week was 50.5 in Group I and 50.1 in Group II, at $6^{\text {th }}$ week was 61.4 in Group I and 59.8 in Group II and at

Table 1: Distribution of patients

\begin{tabular}{lll}
\hline Groups & Group I & Group II \\
\hline Procedure & Citicoline & Cerebroprotein hydrolysate \\
Number & 50 & 50 \\
\hline
\end{tabular}

Table 2: Assessment of BI in both groups

\begin{tabular}{llll}
\hline Groups & Group I & Group II & p-value \\
\hline $1^{\text {st }}$ week & 35.3 & 36.2 & 0.12 \\
$3^{\text {rd }}$ week & 50.5 & 50.1 & 0.15 \\
$6^{\text {th }}$ week & 61.4 & 59.8 & 0.25 \\
$12^{\text {th }}$ week & 65.8 & 64.2 & 0.92 \\
\hline
\end{tabular}

BI: Barthel index 
$12^{\text {th }}$ week was 65.8 in Group I and 64.2 in Group II. The difference was non-significant $(\mathrm{p}>0.05)$

Table 3 and Graph 2 shows that mean mRS at $1^{\text {st }}$ week in Group I was 4.5 and in Group II was 4.2, at $3^{\text {rd }}$ week was 3.6 in Group I and 3.9 in Group II, at $6^{\text {th }}$ week was 3.1 in Group I and 3.6 in Group II and at $12^{\text {th }}$ week was 2.5 in Group I and 2.1 in Group II. The difference was non-significant $(\mathrm{p}>0.05)$.

Table 4 shows that common site was the left middle cerebral artery with $\mathrm{BI}$ index poor seen in 26 , the right middle cerebral artery with $\mathrm{BI}$ index poor in 20, the left internal carotid artery with BI index poor in 17 and posterior cerebral artery with BI index poor in 13 patients.

Table 4 shows that common site was the left middle cerebral artery with poor BI index seen in 18, the right middle cerebral artery with poor BI index in 10, the left internal carotid artery with BI index poor in nine and posterior cerebral artery with BI index poor in 4 patients (Table 5).

\section{DISCUSSION}

Ischemia accounts for $85 \%$ of presentations and $15 \%$ for primary hemorrhage [6]. Hemorrhage is accountable for direct neuronal injury, and the pressure influence causes neighboring ischemia. Primary ischemia occurs from atherothrombotic occlusion or an embolism [7]. The most common sources of embolism are the left atrium in patients with atrial fibrillation followed by the left ventricle in patients with heart failure or myocardial infarction [8]. Vessel constriction ascends

Table 3: Assessment of mRS in both groups

\begin{tabular}{llll}
\hline Groups & Group I & Group II & p-value \\
\hline $1^{\text {st }}$ week & 4.5 & 4.2 & 0.91 \\
$3^{\text {rd }}$ week & 3.6 & 3.9 & 0.82 \\
$6^{\text {th }}$ week & 3.1 & 3.6 & 0.94 \\
$12^{\text {th }}$ week & 2.5 & 2.1 & 0.96 \\
\hline
\end{tabular}

mRS: Modified Rankin scale

Table 4: Site of infarct and functional outcome of BI score

\begin{tabular}{llll}
\hline Site & \multicolumn{2}{l}{ Prognosis } & \multirow{2}{*}{ Total } \\
\cline { 2 - 3 } & Good (BI>90) & Poor (BI<90) & \\
\hline $\begin{array}{l}\text { The left middle } \\
\text { cerebral artery }\end{array}$ & 14 & 26 & 40 \\
$\begin{array}{l}\text { The right middle } \\
\text { cerebral artery }\end{array}$ & 5 & 20 & 25 \\
$\begin{array}{l}\text { The left internal } \\
\text { carotid artery }\end{array}$ & 2 & 17 & 19 \\
$\begin{array}{l}\text { Posterior } \\
\text { cerebral artery }\end{array}$ & 3 & 13 & 16 \\
Total & 24 & 76 & 100 \\
\hline
\end{tabular}

BI: Barthel index

Table 5: Site of infarct and functional outcome of mRS score

\begin{tabular}{llll}
\hline Site & \multicolumn{2}{l}{ Prognosis } & Total \\
\cline { 2 - 3 } & Good (mRS<3) & Poor $(\mathbf{m R S}>\mathbf{3})$ & \\
\hline $\begin{array}{l}\text { The left middle } \\
\text { cerebral artery }\end{array}$ & 22 & 18 & 40 \\
$\begin{array}{l}\text { The right middle } \\
\text { cerebral artery }\end{array}$ & 15 & 10 & 25 \\
$\begin{array}{l}\text { The left internal } \\
\text { carotid artery }\end{array}$ & 10 & 9 & 19 \\
$\begin{array}{l}\text { Posterior } \\
\text { cerebral artery }\end{array}$ & 12 & 4 & 16 \\
Total & 59 & 41 & 100 \\
\hline
\end{tabular}

mRS: Modified Rankin scale from atherosclerosis, characteristically in the internal carotid artery just overhead the carotid bifurcation or from small vessel lesion deep within the brain [9]. Ischemia causes direct injury from inadequate oxygenation and nutritional care. It sets up a series of neurochemical events that lead to spreading damage. The ischemia may be reversible if reperfusion is attained quickly, and the chemical injury may be interrupted by various neuroprotective drugs [10]. The present study was carried out with aim to define outcome in acute stroke patients using $\mathrm{BI}$ and $\mathrm{mRS}$ treated with neuroprotective agents.

In present study, Group I patients were treated with citicoline and Group II with cerebroprotein hydrolysate. Each group had 50 patients. The mean BI at $1^{\text {st }}$ week in Group I was 35.3 and in Group II was 36.2, at $3^{\text {rd }}$ week was 50.5 in Group I and 50.1 in Group II, at $6^{\text {th }}$ week was 61.4 in Group I and 59.8 in Group II and at $12^{\text {th }}$ week was 65.8 in Group I and 64.2 in Group II. Sulter et al. [11] in their study 15 trials satisfying the inclusion criteria were recognized. The BI was used in 13 and the mRS in eight subjects. In four trials mean and median scores of the BI were used, and in one trial median scores of the mRS were equated. BI in seven, the mRS in six, and combined the mRS and BI in three were included as Primary end points. With regard to the BI, a variety of total scores between 50 and 95 were implied as cutoff scores to define promising outcome.

We found that common site was the left middle cerebral artery with BI index poor seen in 26 , the right middle cerebral artery with BI index poor in 20, the left internal carotid artery with BI index poor in 17 and posterior cerebral artery with poor BI index in 13 patients. The common site of occurrence was the left middle cerebral artery with BI index poor seen in 18 , the right middle cerebral artery with poor BI index in 10 , the left internal carotid artery with poor BI index in nine and posterior cerebral artery with poor BI index in 4 patients.

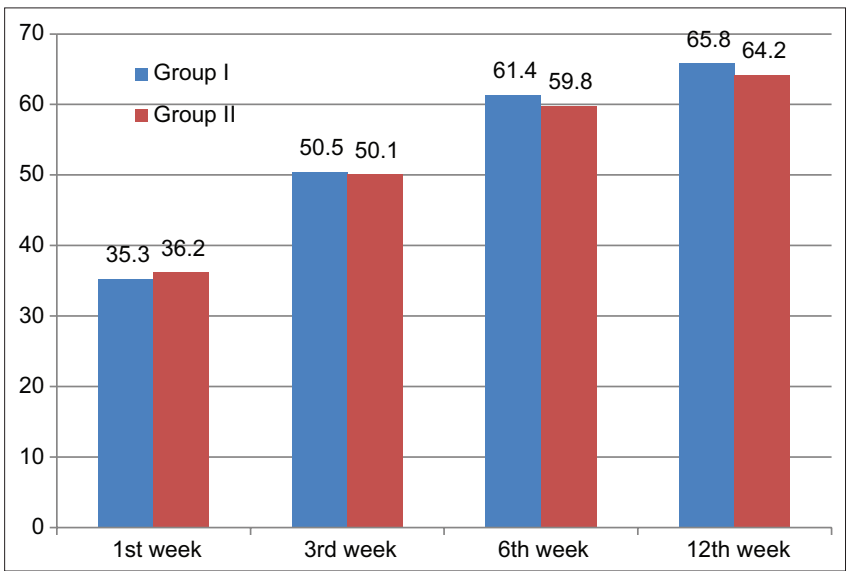

Graph 1: Assessment of Barthel index in both groups

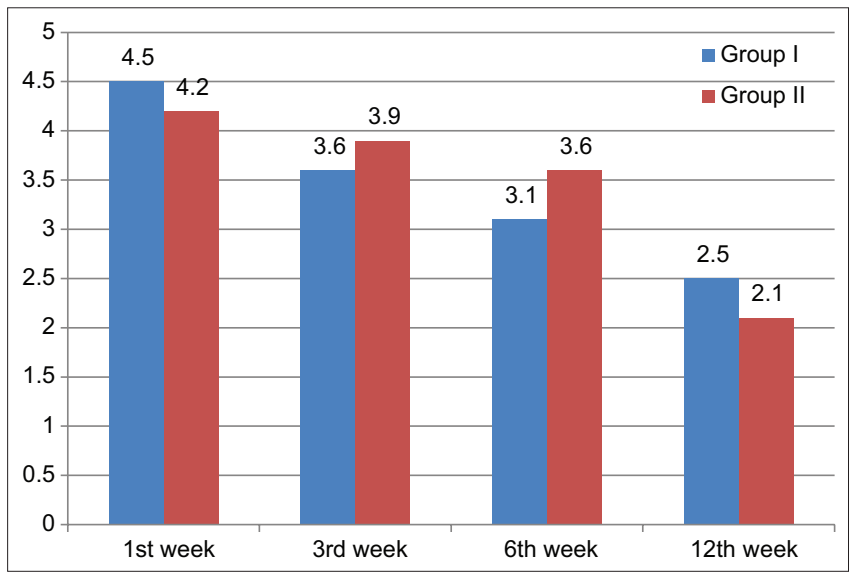

Graph 2: Assessment of Barthel index modified Rankin scale in both groups 
Intravenous recombinant tissue plasminogen activator (rt-PA) is an established therapeutic treatment modality for acute ischemic stroke (AIS) that supports in recanalization of the clogged arteries and mends final functional outcome. The management of AIS includes i/v thrombolytic, maintenance of blood sugar, blood pressure, temperature and increased intracranial pressure, and neuroprotective drugs. About $2-5 \%$ of cases are entitled to receive rt-PA treatment. This has driven the attention in the development of neuroprotective therapies [12]. The limitation of the study is small sample size.

\section{CONCLUSION}

Authors found that correlation between BI and mRS from baseline to end of 12 weeks within each group was highly significant.

\section{AUTHORS' CONTRIBUTIONS}

Dr. Inder pal Singh involved in data collection, data analysis, data interpretation, and writing the manuscript. Dr. Kamaldeep Kaur involved in data analysis, data interpretation, and writing the manuscript. Dr. Lovleen Bhatia involved in supervising entire research work, along with writing and finalizing the manuscript. Dr. Ajay pal involved in data analysis, data interpretation, and proof reading the manuscript.

\section{CONFLICTS OF INTEREST}

No conflicts of interest to disclose.

\section{AUTHORS' FUNDING}

This research study did not receive any external funding.

\section{REFERENCES}

1. Grotta J. Lubeluzole treatment of acute ischemic stroke. The US and Canadian lubeluzole ischemic stroke study group. Stroke 1997;28:2338-46.
2. Diener HC. Multinational randomised controlled trial of lubeluzole in acute ischaemic stroke. European and Australian Lubeluzole Ischaemic Stroke Study Group. Cerebrovase Dis 1998;8:172-81.

3. Davis SM, Albers GW, Diener HC, Lees KR, Norris J. Termination of acute stroke studies involving selfotel treatment. ASSIST Steering Committed. Lancet 1997;349:32

4. Yamaguchi T, Sano K, Takakura K, Saito I, Shinohara Y, Asano T, et al. Ebselen in acute ischemic stroke: A placebo-controlled, double-blind clinical trial. Ebselen Study Group. Stroke 1998;29:12-7.

5. Kay R, Wong KS, Yu YL, Chan YW, Tsoi TH, Ahuja AT, et al. Lowmolecular-weight heparin for the treatment of acute ischemic stroke. N Engl J Med 1995;333:1588-93.

6. Low molecular weight heparinoid, ORG 10172 (danaparoid), and outcome after acute ischemic stroke: A randomized controlled trial. The publications committee for the trial of ORG 10172 in acute stroke treatment (TOAST) investigators. JAMA 1998;279:1265-72.

7. Hacke W, Kaste M, Fieschi C, Toni D, Lesaffre E, von Kummer R, et al. Intravenous thrombolysis with recombinant tissue plasminogen activator for acute hemispheric stroke. The European Cooperative Acute Stroke Study (ECASS). JAMA 1995;274:1017-25.

8. Hacke W, Kaste M, Fiechi C, von Kummer R, Davalos A, Meier D, et al. Randomised double-blind placebo-controlled trial of thrombolytic therapy with intravenous alteplase in acute ischaemic stroke (ECASS II). Second European-Australasian acute stroke study investigators. Lancet 1998:352:1245-51.

9. The National Institute of Neurological Disorders and Stroke rt-PA Stroke Study Group. Tissue plasminogen activator for acute ischemic stroke. N Engl J Med 1995;333:1581-7.

10. Multicenter Acute Stroke Trial-Europe Study Group, Hommel M, Cornu C, Boutitie F, Boissel JP. Thrombolytic therapy with streptokinase in acute ischemic stroke. N Engl J Med 1996;335:145-50.

11. Sulter G, Steen C, de Keyser J. Use of the Barthel index and modified Rankin scale in acute stroke trials. Stroke 1999;30:1538-41.

12. Mehta A, Mahale R, Buddaraju K, Javali M, Acharya P, Srinivasa R. Efficacy of neuroprotective drugs in acute ischemic stroke: Is it helpful? J Neurosci Rural Pract 2019;10:576-81. 